\title{
Temporay ponds from Doñana National Park: a system of natural habitats for the preservation of aquatic flora and fauna
}

\author{
Carmen Díaz-Paniagua ${ }^{1, *}$, Rocío Fernández-Zamudio², Margarita Florencioº ${ }^{2}$, Pablo García- \\ Murillo $^{2}$, Carola Gómez-Rodríguez ${ }^{1}$, Alexandre Portheault ${ }^{1}$, Laura Serrano ${ }^{2}$ and Patricia Sil- \\ jeström ${ }^{3}$
}

${ }^{1}$ Estación Biológica de Doñana-CSIC, Apartado 1056, 41080 Sevilla, Spain.

2 Dept. Plant Biology and Ecology, Univ. Sevilla.

${ }^{3}$ Instituto de Recursos Naturales y Agrobiología Sevilla-CSIC.

*Corresponding author: poli@ebd.csic.es

Received: 27/2/09

Accepted: $24 / 6 / 09$

\begin{abstract}
Temporay ponds from Doñana National Park: a system of natural habitats for the preservation of aquatic flora and fauna

Mediterranean temporary ponds are a priority habitat under the European Union Habitats Directive, but those of natural origin are scarce, as many of them have been destroyed or transformed into permanent waters. The aim of this study is to highlight the conservation value of the system of temporary ponds in Doñana National Park, where more than 3000 water bodies may be filled during wet years. They are located on soils of aeolian origin where water persistence is favoured by the presence of an argilic semi permeable horizon and by a relic clay-rich sandy layer. Temporary ponds can be classified across a wide hydroperiod gradient. Most ponds fill with autumnal or winter rains and persist up to late spring or summer, and only a few may persist through summer. Eight of the 11 amphibian species of this area require temporary ponds for breeding. More than 124 taxa of macroinvertebrates have been recorded, coleopterans (56 taxa) and heteropterans (19 taxa) being the richest taxonomic groups. Several zooplankton species are endemic to this kind of habitats, such as the copepod Dussartius baeticus and the rotifer Lecane donyanensis. Regarding vegetation, at least 55 hydrophytes species were identified in the ponds sampled, and also some species endemic to SW Iberian Peninsula (Callitriche regis-jubae, Scorzonera fistulosa, Callitriche lusitanica) and others are in relic situation (Hydrocharis morsus-ranae, Thorella verticillato-inundata, Lemna trisulca). The conservation value of these ponds is highlighted by the large variety of protected and/or rare species of flora and fauna, which are favoured by a high pond abundance and connectivity.
\end{abstract}

Key words: Temporary ponds, conservation, aquatic fauna, aquatic vegetation, macroinvertebrates, amphibians.

\section{RESUMEN}

Las lagunas temporales del Parque Nacional de Doñana: un sistema de hábitats naturales para la conservación de la flora y fauna acuáticas

Las lagunas temporales mediterráneas son hábitats prioritarios incluidos en la Directiva de Hábitats de la Unión Europea, que han sido frecuentemente destruídos o transformados en medios permanentes, siendo actualmente escasos los de origen natural. Este estudio pretende resaltar la importancia que tiene el sistema de charcas temporales del Parque Nacional de Doñana en la conservación de flora y fauna acuáticas. Este sistema comprende más de 3000 cuerpos de agua en años lluviosos, localizándose en las zonas de origen eólico, donde la permanencia del agua se ve favorecida por la presencia en sus suelos de un horizonte argílico y semipermeable y por una capa arenosa relicta rica en arcillas. Las lagunas temporales se pueden clasificar en función de su amplio gradiente de hidroperiodo. La mayoría de ellas se llenan con las lluvias de otoño o invierno y pueden permanecer hasta el final de la primavera o principios del verano y sólo algunas pueden mantener agua en verano. Las lagunas temporales son los hábitats de reproducción de ocho de las 11 especies de anfibios que se encuentran en Doñana. Se registraron más de 124 taxa de macroinvertebrados, entre los que los coleópteros (56 taxa) y heterópteros (19 taxa) fueron los grupos taxonómicos con mayor número de especies. En el zooplancton, destacan especies endémicas de 
este área, como el copépodo Dussartius baeticus y el rotífero Lecane donyanensis. Entre las especies vegetales características de las lagunas temporales se han identificado más de 55 hidrófitos, encontrándose además algunos endemismos del suroeste ibérico (Callitriche regis-jubae, Scorzonera fistulosa, Callitriche lusitanica), así como especies amenazadas (Hydrocharis morsus-ranae, Thorella verticillato-inundata, Lemna trisulca). Las lagunas temporales de Doñana son de gran importancia para la conservación de un amplio número de especies protegidas y singulares de su flora y fauna acuática, que se ven favorecidas por la gran abundancia y conectividad de medios acuáticos.

Palabras clave: Lagunas temporales, conservación, fauna acuática, vegetación acuática, macroinvertebrados, anfibios.

\section{INTRODUCTION}

Temporary ponds are aquatic environments with recurrent periods of desiccation. Therefore, their aquatic flora and fauna is forced to endure the dry period through different mechanisms, such as complex life cycles including terrestrial phases, phases of resistance or dispersal to other habitats (Brönmark \& Hansson, 2005; Williams, 2006). Strict aquatic species may not survive in these ponds. Another important characteristic of these habitats is the absence of predators common to permanent waters, mainly fishes, which influences the structure of their animal communities (Wellborn et al., 1996). In consequence, temporary ponds support a different community structure than permanent waters do (Collinson et al., 1995; Schneider \& Frost, 1996; Della Bella et al., 2005; Céréghino et al., 2008) and hence deserve specific conservation and management programs.

For many years, conservation of aquatic ecosystems has been mainly directed to permanent waters. Temporary ponds have often been inconspicuous and poorly known due to their temporary nature and small size, and have been frequently destroyed by human action (Williams et al., 2001; Grillas et al., 2004; Williams, 2006; Zacharias et al., 2007). In particular, conservation of temporary ponds is essential for species that may not survive in more permanent aquatic habitats, such as some species of macrophytes (Nicolet et al., 2004; Della Bella et al., 2008), macroinvertebrates (Collinson et al., 1995; Nicolet et al., 2004; Cayrou \& Céréghino, 2005; Bilton et al., 2008), and amphibians (Díaz-Paniagua, 1990; Griffiths, 1997; Semlitsch, 2003).
Mediterranean temporary ponds are a priority habitat under the European Union Habitats Directive (Code 3170: European Commission DG Environment, 2007). They present a wide variability in filling onset and duration, depending on rainfall input and pattern (Zacharias et al., 2007). However they may be distinguished from other types of temporary ponds because they are mostly flooded in autumn or spring and dry out for several months in summer (Grillas et al., 2004). Mediterranean temporary ponds of natural origin are scarce, as their importance is often not appreciated and many of them have been destroyed or transformed in permanent water (Grillas et al., 2004). In this category there are also included many ponds derived from human activities, for example those used in agriculture for livestock watering (Beja \& Alcazar, 2003; Denoël, 2004; Stamati et al., 2008) or gravel and mining pits of historic origin (Jakob et al., 2003).

The Doñana National Park is one of the most important wetland areas in Western Europe, being UNESCO Biosphere Reserve and Ramsar site (see e.g. García Novo \& Marín, 2006). However, despite comprising a large number of small Mediterranean temporary ponds (see Gómez-Rodríguez et al. 2008; Gómez-Rodríguez, 2009), these have been frequently disregarded in most faunistic and ecological studies which have traditionally focused on the marshes (García Novo \& Marín, 2006) and large ponds (López et al., 1991; Serrano \& Toja, 1995; Serrano et al., 2006).

The aim of this study is to highlight the conservation value of this system of Mediterranean temporary ponds for the preservation of aquatic flora and fauna. As a mainly descriptive paper, we 
have reviewed the previous information on faunistic and plant studies of these habitats and we have also recorded new data to assess pond biodiversity in different time periods. Our purpose was: 1) to bring out the existence of this temporary ponds system as an example of Mediterranean temporary ponds of singular importance for their natural origin and for their present conservation value, 2) to describe the high species richness of different taxonomical groups in these habitats and 3) to describe the wide variation that the composition of these communities may experience among different ponds and years.

\section{MATERIALS AND METHODS}

\section{Description of the study area}

The Doñana National Park is located on the right bank of the Guadalquivir River mouth, in southwestern Spain. From a geomorphogical viewpoint, it comprises three different landscapes: a marsh area, a mobile dune system running parallel to the coast and a stable, older dune system, which occupies almost a third of the total Park surface (Siljeström \& Clemente, 1990). In the stable dunes region, the geomorphology and

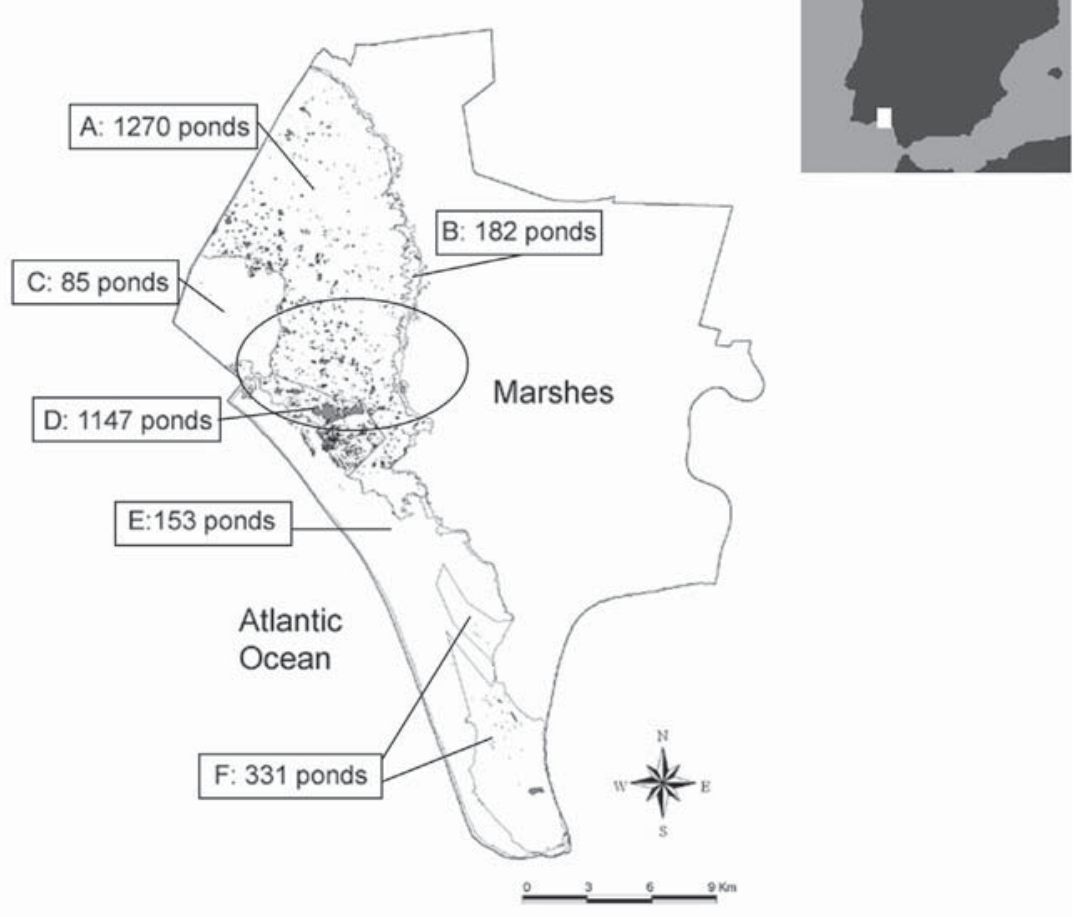

Figure 1. Main different ecological units within Doñana National Park, with the number of ponds estimated in each zone in 2004 (pond cartography extracted from Gómez-Rodríguez, 2009). A: Northern stable dunes; B: Contact area between stable dunes and marshes; C: Higher stable dunes; D: Contact area between stable and mobile dunes (peridune area); E: Mobile dunes; F: Southern stable dunes. The 18-21 ponds intensively sampled were located in the area included in the ellipse. Ninety ponds sampled once in 2006 or 2007 were located through all the sandy area of the Park. Principales unidades ecologicas que se distinguen en el Parque Nacional de Doñana, indicándose el número de lagunas estimadas en cada zona en el año 2004 (cartografía de lagunas extraída de Gómez-Rodríguez, 2009). A: Arenas estabilizadas del Norte; B: Área de contacto entre arenas estabilizadas y marismas; C: Arenas estabilizadas de mayor altitud; D: Área de contacto entre arenas estabilizadas y dunas móviles (área peridunar); E: Dunas móviles; F: Arenas estabilizadas del Sur. Las 18-21 lagunas muestreadas con mayor intensidad se localizan dentro del área enmarcada por la elipse. Las 90 lagunas que se muestrearon una sola vez en 2006 o 2007 se encuentran distribuidas por las zonas arenosas de todo el Parque. 
water table depth are the main factors affecting the landscape and soil classification, which will influence the density and extent of their aquatic environments. The northern part of the stable dune area (Fig. 1 A) is much older and eroded than the southern part (Fig. 1 F), constituting the Eroded Sand Sheet, and is where the main part of the temporary pond system is located. The watertable is close to the surface and the ground gets flooded during wet periods, creating a great number of temporary ponds. The southernmost part (Fig. $1 \mathrm{~F}$ ), of recent formation and different soil composition, contains ridges and small depressions in which ponds are also created during the rainy period. The Mobile Dune System (Fig. 1 E) is very dry, with the exception of some of the interdune valleys, due to the proximity of the watertable (Siljeström \& Clemente, 1990).

In contact areas between these landscapes, many ponds are formed (Gómez-Rodríguez, 2009) as result of discharges from the watertable. In the limit of the mobile dunes with the stable dune system (Fig. 1 D), the two nearlypermanent ponds of the Park may be found, as well as a number of temporary ponds of wide extension and shallow depth filled with drainage from the aquifer of the mobile dune system and of the eroded sand sheet. On the other hand, in the border between the marsh and the stable dunes
(Fig. 1 B), ponds of different characteristics can also be found (Siljeström et al., 1994).

The climate of the area is Mediterranean with Atlantic influence, with warm and dry summers and mild winters. Average annual rainfall is $544.6( \pm 211.3) \mathrm{mm}$ (as recorded from 19782008), with heavy rains mainly falling in autumn or in winter (Fig. 2) thus flooding the temporary ponds after their summer desiccation.

\section{Sampling and field work methods}

In this study we have included data of annual rainfall recorded in a meteorological station located within the study area from 1978 to 2008. Annual rainfall data corresponded to the sum of monthly rainfall from September to the next $\mathrm{Au}-$ gust. Within this time period we were recording data for different studies in temporary ponds in two periods: Between 1978 and 1985, and between 1999 and 2008. In the first period we monitored amphibian species in 12 temporary ponds, for which we recorded data on filling and desiccation and the monthly variation of their maximum depth. In the second period we intensively monitored 18 ponds for studies on amphibians, and 21 ponds (the previous $18+3$ additional ponds) for macroinvertebrates and plant communities, and recorded soil samples. Six of the

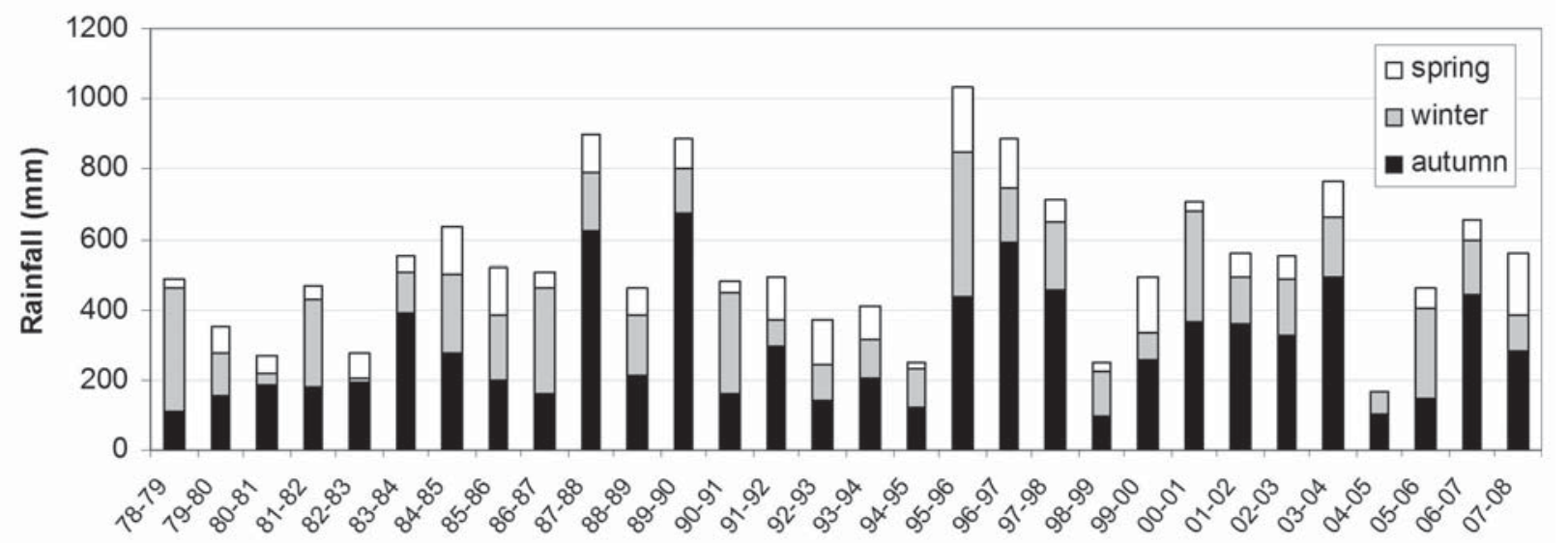

Figure 2. Annual rainfall in Doñana from 1978-2008. Each annual period includes data from September-August, classified in seasonal periods. Precipitación anual registrada en Doñana entre 1978 y 2008. Cada periodo anual incluye datos de Septiembre a Agosto, clasificados en periodos estacionales. 
ponds sampled in the first period were also sampled in the second period, providing a long time series of data on their hydroperiod and amphibian data. Pond hydroperiod was estimated as the number of months a pond was flooded.

The number of ponds of the area was estimated with remote sensing analyses on a hyperspectral image taken at a moment of large inundation (see Gómez-Rodríguez et al., 2008; Gómez-Rodríguez, 2009 for details).

The soil of 21 ponds was prospected, sampled and described (using FAO, 1977; IUSS Working Group WRB, 2006; and Soil Survey Staff, 1993 ; 2006) by taking more than 60 boreholes in their basins in 2007. Abundance of amphibians were monthly sampled in 18 temporary ponds during the inundation period from October 2002 to July 2007 , and macroinvertebrates and plants were monitored in the same 18 ponds and three additional ones in 2006-2007. Amphibian larvae and macroinvertebrates were sampled with a dipnet of $1 \mathrm{~mm}$ of mesh size, with which we covered a length of approximately $1.5 \mathrm{~m}$ and was repeated, at least in 12 zones of the pond for amphibians and 6 for macroinvertebrates, whenever possible. The amphibian larvae and macroinvertebrates captured were identified in situ and counted and then released back to the ponds. Only some individuals of those species not identified in situ were preserved in $70 \%$ ethanol for further identification. All other individuals captured were released in the pond. Macroinvertebrates were identified using the highest taxonomical resolution possible (usually species or genus), except for Dipterans in which only Families were identified. We have used the term "taxa" to count all different species, genera or families detected in the ponds. The same ponds were surveyed to record the presence of hydrophytes species around and within the ponds, especially on the same points where macroinvertebrates samples were recorded. All plants were identified to species level in laboratory using reference bibliography (Valdés et al., 1987; Cirujano et al., 2007). The hydroperiod of these ponds were classified in relation to the duration of the flooded period in 2006-07: a) small ponds of short duration (3-5 months); $b$ ) intermediate tempo- rary ponds (5-6 months); c) extensive temporary ponds of long duration (> 6 months); $d$ ) ponds artificially deepened to hold water during summer (locally named zacallones).

Additionally, 90 ponds were also sampled at least once in 2006 and 2007, recording presence data on macroinvertebrates, amphibians and plants. The physico-chemical characterization of these ponds water was based on data obtained in spring 2007 (April-May). We measured maximum depth, electrical conductivity (compensated at $25^{\circ} \mathrm{C}$ ), and $\mathrm{pH}$ in situ, and collected water samples for later determination of alkalinity and concentrations of dissolved inorganic phosphate (i-P), $\mathrm{NH}_{4}^{+}, \mathrm{SO}_{4}^{+}, \mathrm{Cl}^{-}, \mathrm{Ca}^{2+}, \mathrm{K}^{+}$, $\mathrm{Mg}^{2+}$, and $\mathrm{Na}^{+}$in the laboratory.

For those taxonomic groups which had been intensively studied in this area, we also provide information from previous studies describing the number of species, and the main characteristics of the groups related to their ecology in temporary ponds, as in the case of planktonic microcrustaceans and rotifers.

Although we performed intensive surveys on macroinvertebrates and amphibians for the most recent period, in this study we only use these data to describe the importance of faunistic variation among ponds and years, while other ecological aspects of the macroinvertebrates and amphibian assemblages of these ponds are being the object of more specific studies (see e.g. Gómez-Rodriguez, 2009; Florencio et al., 2009). Therefore, in this study we have tried to simplify our data by extracting the information most representative of different types of ponds, selecting the results of six out of 18 ponds to represent the variation in pond depth, and of only three ponds for the variation in interannual amphibian larvae abundances.

\section{RESULTS}

\section{Geomorphology and Soils: Characterization of Pond Types}

Different soil structure was appreciated in ponds in relation to the different zones in which they were located. In Northern stable dunes, ponds 
had longer evolution time, and soils showed a superficial, well developed, horizon of silty texture due to the high organic matter content (satisfying the conditions of an Umbric or Mollic epipedon, Typic Humaquepts or Typic Haplaquolls) depending on the saturation. Other soils presented Mio-Pliocene semipermeable sediments nearer to the pond ground surface, favouring the water accumulation. In fact, these water dynamics may cause a fine sediment layer accumulation which can act, through a positive feedback process, as a hanging water table. As a result, an argilictype horizon in the profile may be identified (appearing between 30 and $60 \mathrm{~cm}$ and with variable thickness), which leads to a Typic Ochraqualf classification. At the border of the mobile dune system, in its contact with the stable dunes, there are ponds which are nearly permanent with a hypogenic origin, fed from a deep water-table. They showed no discontinuities in the profile and were characterized by a strong hydromorphic processes in their profile, where an aquic soil moisture regime can be defined (classified as Aquic Xeropsamments to Humaqueptic Psammaquents). The most evolved soils presented a well developed organic horizon which can be defined as Umbric epipedon (Typic Humaquepts). In the southern stable dunes, ponds showed the same characteristics as those located on the rest of sandy soils with the exception of shell layers that conferred them a certain amount (up to a $20 \%$ in the first $25 \mathrm{~cm}$ ) of $\mathrm{CO}_{3} \mathrm{Ca}_{2}$ (Aeric to Typic Calciaquolls). Finally, ponds located in the contact area between the stable dunes and the marsh are characterized by a soil profile where multiple clayey interdigitations may be found (Thapto Psammentic Pelloxererts, among others) (Siljeström, 1985).

\section{Number of ponds}

At the time of a large inundation event (April 2004), more than 3000 water bodies were identified (see Gómez-Rodríguez, 2009 for details on this cartography). Ponds were not uniformly distributed in the area, being the northern stable sands the area with the highest number of ponds (Fig. 1, A). The driest areas of the Park corresponded to the mobile dunes (Fig. 1, E) and the high stable sands (Fig. 1, C), with ponds occurring only at lower altitudes on the stable sands. In the southern stable sands (Fig. 1, F), most ponds were man-made permanent water bodies consisting in deep and small $\left(<10 \mathrm{~m}^{2}\right)$ pits made for cattle drinking during summer (zacallones).

\section{Interannual variation in rainfall and pond hydroperiod}

Over the study period, we observed a wide variability in annual rainfall and seasonality (Fig. 2). From 1978-2007, we detected 5 very wet years with annual rainfall $>712.8 \mathrm{~mm}$ and autumn heavy rains, and 5 very dry years with annual rainfall below $353.4 \mathrm{~mm}$.

Ponds generally filled after the first heavy rains. We have recorded the date of pond filling in 14 years: it occurred in autumn for 8 years, and in winter for 6 years. Additionally, in two very dry years, temporary ponds were not flooded (1998-99 and 2004-05). Ponds filled the month in which rainfall accumulated an average of $255.1 \mathrm{~mm}(\mathrm{sd}=54.2)$ since August. We detected a significant correlation between the month of pond filling and the month when cumulative rainfall reached or surpassed $200 \mathrm{~mm}$ $\left(r_{\text {Spearman }}=0.952, p=0.00001\right)$.

In order to illustrate the wide variation in depth and hydroperiod that a same pond may experience among contrasting hydrological years we selected six of the 21 ponds sampled in two years of different rainfall: 2005-06 an annual period of scarce rainfall and 2006-07, a rainy period (Fig. 3). As these six ponds included the largest variation in hydroperiod, we did not include other studied ponds of similar variation. Ponds were flooded in November in the wet year, when those ponds with a shorter hydroperiod dried in May, persisting 6 months. Others persisted until June or July, with a hydroperiod of 8-9 months. Additionally, in this wet year, other ephemeral ponds were flooded later and persisted about 3 months. In the drier year, ponds neither filled in autumn nor in winter, but in late January, and the pond with the longest hydroperiod persisted for 5 months until July. The most ephemeral ponds of the wet year did not fill during the dry one, 

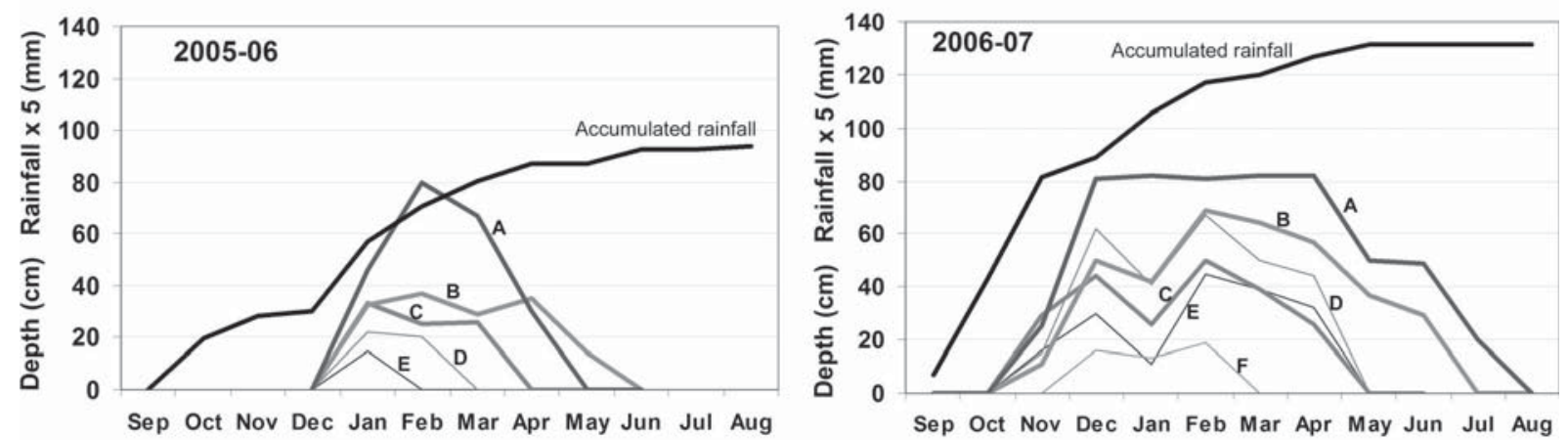

Figure 3. Cumulative rainfall and depth of six temporary ponds in two different years: 2005-06 (annual rainfall $=468 \mathrm{~mm}$ ) and 2006-07 (annual rainfall $=655 \mathrm{~mm}$ ). A, B, C, D, E and F were the same ponds in both years (F was not filled in the first year). Precipitación acumulada y profundidad de seis lagunas temporales en dos años de características diferentes: 2005-06 (precipitación anual $=468 \mathrm{~mm}$ ) y 2006-07 (precipitación anual $=655 \mathrm{~mm}$ ). A, B, C, D, E y F corresponden a las mismas lagunas en ambos periodos ( $F$ no se inundó durante el primer año).

and short-hydroperiod ponds persisted only 1-3 months. Ponds reached a higher extension and depth during the rainy year.

\section{Physico-chemistry of the ponds}

Water physico-chemistry of ponds ranged widely across the National Park during spring 2007 (Table 1). In general, most ponds were shallow $(<1 \mathrm{~m})$ freshwater environments with a circumneutral $\mathrm{pH}$ and low ionic concentrations dominated

Table 1. Minimum, maximum and median values of main physico-chemical variables of temporary ponds in the study period ( $n=$ number of ponds sampled). Valores mínimo, máximo $y$ medianas de las principales variables fisico-químicas de las lagunas temporales en el periodo de estudio $(\mathrm{n}=$ número de lagunas muestreadas).

\begin{tabular}{lcccc}
\hline Variable & min & max & median & $n$ \\
\hline water depth $(\mathrm{cm})$ & 9 & 124 & 70 & 90 \\
E.C. $\left(\mathrm{mS} \mathrm{cm}^{-1}\right)$ & 0.09 & 9.87 & 0.50 & 90 \\
pH & 5.4 & 10.4 & 6.8 & 87 \\
Alkalinity $\left(\mathrm{meq} \mathrm{L}^{-1}\right)$ & 0.10 & 15.97 & 2.52 & 39 \\
$\mathrm{Cl}^{-}\left(\mathrm{meq} \mathrm{L}^{-1}\right)$ & 0.55 & 30.99 & 2.37 & 39 \\
$\mathrm{Na}^{+}\left(\mathrm{meq} \mathrm{L}^{-1}\right)$ & 0.02 & 27.56 & 2.98 & 39 \\
$\mathrm{Ca}^{2+}\left(\mathrm{meq} \mathrm{L}^{-1}\right)$ & 0.05 & 7.25 & 1.15 & 39 \\
$\mathrm{Mg}^{2+}\left(\mathrm{meq} \mathrm{L}^{-1}\right)$ & 0.18 & 11.99 & 0.98 & 39 \\
$\mathrm{SO}_{4}^{2-}\left(\mathrm{meq} \mathrm{L}^{-1}\right)$ & 0.04 & 2.89 & 0.36 & 39 \\
$\mathrm{~K}^{+}\left(\mathrm{meq} \mathrm{L}^{-1}\right)$ & 0.02 & 1.74 & 0.14 & 39 \\
$\mathrm{NH}_{4}^{+}\left(\mathrm{mg} \mathrm{L}^{-1}\right)$ & 0.04 & 3.59 & 0.04 & 90 \\
$\mathrm{i}-\mathrm{P}\left(\mu \mathrm{g} \mathrm{L}^{-1}\right)$ & 10 & 750 & 10 & 90 \\
\hline
\end{tabular}

by $\mathrm{NaCl}$. The concentration of dissolved inorganic phosphate was generally very low in spring 2007 .

\section{The vegetation of the ponds}

A total number of 55 plant species were found in the 21 temporary ponds sampled monthly (Table 2). We differentiated three main groups of hydrophytes: hygrophytes, submerged macrophytes and floating macrophytes. The first group included non strict aquatic plants, in which a subset of typical wet meadows species (floodplain species) were usually the main vegetation in ponds of short hydroperiod. Among these, graminean species such as Agrostis stolonifera, Paspalum paspalodes and Cynodon dactylon were the most abundant, being frequently accompanied by other weeds as Mentha pulegium, Baldellia ranunculoides, Myosotis ramosisssima or Illecebrum verticillatum.

Another subgroup of helophytes is wetland species, which inhabit the borders of ponds. In Doñana it included Juncus maritimus, Eleocharis palustris and Eleocharis multicaulis among others. In deeper zones of the ponds, some species of submerged and floating macrophytes were frequent. The most common species were Juncus heterophyllus and Ranunculus peltatus, as well as Scirpus fluitans and different species of Charophytes. In the deepest zones, the main vegetation is represented by submerged plants, such 
Table 2. Plant species recorded in 21 temporary ponds intensively surveyed and other species with special conservation value recorded in additional ponds through the Doñana National Park. ${ }^{1}$ : semipermanent or zacallones; ${ }^{2}$ : long duration ponds $;{ }^{3}:$ intermediate duration ponds; ${ }^{4}$ : short duration ponds; *: exotic invasive species. Especies de plantas registradas en las 21 lagunas temporales que fueron muestreadas intensivamente, y especies con especial valor de conservación registradas en otras lagunas temporales del Parque Nacional de Doñana. ${ }^{1}$ : semipermanentes o zacallones; ${ }^{2}$ : lagunas temporales de larga duración; ${ }^{3}$ : lagunas de duración intermedia; ${ }^{4}$ : lagunas de corta duración; *: especies exóticas invasoras.

\begin{tabular}{|c|c|c|c|}
\hline \multicolumn{2}{|c|}{ Helophytes } & \multicolumn{2}{|l|}{ Macrophytes } \\
\hline Floodplain species & Wetland species & Anchored (submerged or floating leaves) & Free-floating \\
\hline Agrostis stolonifera ${ }^{1234}$ & Cyperus longus 1234 & Apium inundatum 234 & Azolla filiculoides ${ }^{2 *}$ \\
\hline Anagallis arvensis ${ }^{1}$ & Eleocharis multicaulis ${ }^{1234}$ & Callitriche brutia ${ }^{1234}$ & Lemna minor ${ }^{12}$ \\
\hline Anagallis tenella $^{12}$ & Eleocharis palustris ${ }^{1234}$ & Callitriche obtusangula ${ }^{1234}$ & \\
\hline Baldellia ranunculoides ${ }^{1234}$ & Galium palustre 124 & Callitriche truncata subsp occidentalis ${ }^{1}$ & \\
\hline Cotula coronopifolia ${ }^{1234}$ & Juncus maritimus ${ }^{1234}$ & Chara aspera ${ }^{12}$ & \\
\hline Cynodon dactylon ${ }^{1234}$ & Juncus pygmaeus $^{2}$ & Chara connivens $^{12}$ & \\
\hline Elatine alsinastrum $^{2}$ & Scirpus cernuus $^{12}$ & Juncus heterophyllus ${ }^{1234}$ & \\
\hline Elatine hexandra ${ }^{1}$ & Scirpus holoschoenus ${ }^{1234}$ & Myriophyllum alterniflorum ${ }^{123}$ & \\
\hline Eryngium corniculatum ${ }^{12}$ & Scirpus litoralis 12 & Nitella flexilis $^{12}$ & \\
\hline Frankenia laevis 1234 & Scirpus maritimus ${ }^{12}$ & Nitella tenuisissima $a^{2}$ & \\
\hline Glyceria spicata $^{1234}$ & Scirpus pseudosetaceus ${ }^{14}$ & Nitella translucens ${ }^{34}$ & \\
\hline Hydrocotile vulgaris ${ }^{12}$ & & Potamogeton lucens $^{13}$ & \\
\hline Hypericum elodes ${ }^{12}$ & & Potamogeton pectinatus $^{23}$ & \\
\hline Illecebrum verticillatum ${ }^{1234}$ & & Ranunculus peltatus ${ }^{1234}$ & \\
\hline Imperata cylindrica $^{1}$ & & Ranunculus tripartitus ${ }^{124}$ & \\
\hline Lotus pedunculatus ${ }^{13}$ & & Scirpus fluitans $^{2}$ & \\
\hline Lotus subbiflorus ${ }^{23}$ & & Zannichellia obtusifolia ${ }^{1}$ & \\
\hline \multicolumn{4}{|l|}{ Lythrum junceum ${ }^{1234}$} \\
\hline \multicolumn{4}{|l|}{ Mentha pulegium ${ }^{1234}$} \\
\hline \multicolumn{4}{|l|}{ Myosotis ramosissima ${ }^{1234}$} \\
\hline \multicolumn{4}{|l|}{ Panicum repens 1234} \\
\hline \multicolumn{4}{|l|}{ Paspalum paspalodes ${ }^{1234}$} \\
\hline \multicolumn{4}{|c|}{ Ranunculus ophioglossifolius ${ }^{1234}$} \\
\hline \multicolumn{4}{|l|}{ Rumex sp ${ }^{34}$} \\
\hline Silene laeta ${ }^{2}$ & & & \\
\hline
\end{tabular}

Other species with special conservation value collected in temporary ponds in Doñana

\begin{tabular}{lll}
\hline Damasonium alisma & Potamogeton natans & Lemna trisulca \\
Ludwigia palustris & Potamogeton polygonifolius & Lemna gibba \\
Thorella verticillato-inundata & Hydrocharis morsus-ranae & Wolffia arrhiza \\
Scorzonera fistulosa & Callitriche regis-jubae & Rallitriche lusitanica \\
& & \\
\end{tabular}

as Myriophyllum alterniflorum and Callitriche obtusangula. In the deepest ponds, mainly those which have been artificially deepened and water may persist in small areas during the summer, it is possible to find macrophytes common in permanent waters, such as Potamogeton lucens.

\section{Fauna of the ponds}

Zooplankton: Several previous studies have shown that the temporary ponds of Doñana support a rich and dynamic community of zooplankton (Mazuelos et al., 1993; Fahd et al., 2000; 
Serrano \& Fahd, 2005). In total, over 150 zooplankton species have been listed in the Doñana ponds: 78 micro-crustaceans (Fahd et al.,2009) and 74 rotifers (García-Novo \& Marín, 2006). Besides many cosmopolitan species, there are also species endemic to Doñana, such as the rotifer Lecane donyanaensis (Galindo et al., 1994). A few other species are endemic to the Iberian Peninsula-Balearic Isles, such as Daphnia hispanica (Alonso, 1996) while others have a restricted distribution to SW Iberia, such as the copepod Dussartius baeticus. More recently, some exotic crustacean species have been reported across Doñana, such as the cladoceran Daphnia parvula in the freshwater ponds (Serrano \& Fahd, 2005).

Macroinvertebrates: a total of 124 taxa of macroinvertebrates were recorded in the area (the complete list is given in Florencio et al. 2009) (Table 3). Among Coleoptera, we recorded 56 taxa. Dytiscidae was the family that included more taxa (21 species). Hydrophilidae was also a diverse family, with at least 14 species. We detected species with special interest for conservation, such as Coenagrion scitulum (Odonata: Coenagrionidae) and Lestes macrostigma (Odonata: Lestidae) which are vulnerable species in the IUCN Red List (Verdú \& Galante, 2005). Four species of Coleoptera with a restricted distribu- tion (North Africa and the Central and South of the Iberian Peninsula) were recorded: Hygrotus lagari, Hydroporus lucasi, Cybister tripunctatus africanus and Lacobius revelieri. Of these, $\mathrm{H}$. lagari and $H$. lucasi were abundant and occurred in most of the temporary ponds sampled. Other endemic species for the Iberian Peninsula recorded in Doñana temporary ponds were Haliplus andalusicus or Rhantus hispanicus.

The total number of macroinvertebrate taxa recorded per pond is shown in figure 4. Most of them occurred in $25-50 \%$ of the ponds. The ponds with lower richness were those of shorter hydroperiod, which also included species which were not frequent in other types of ponds, therefore contributing to increase the total richness in the area (Fig. 4). For example, coleopterans Laccobius revelierei and Agabus dydimus were only found in ponds with hydroperiod of less than 6 months.

Amphibians: Eleven of the total 13 species of amphibians occurring in SW Spain are present in Doñana. Their abundance and distribution has been described previously (Díaz-Paniagua et al., 2005; 2006), as well as their breeding strategies (Díaz-Paniagua, 1988; 1990; 1992), summarized in table 4. Eight of the 11 species are typical breeders of temporary ponds, and are abundant or very abundant in the area; another species,

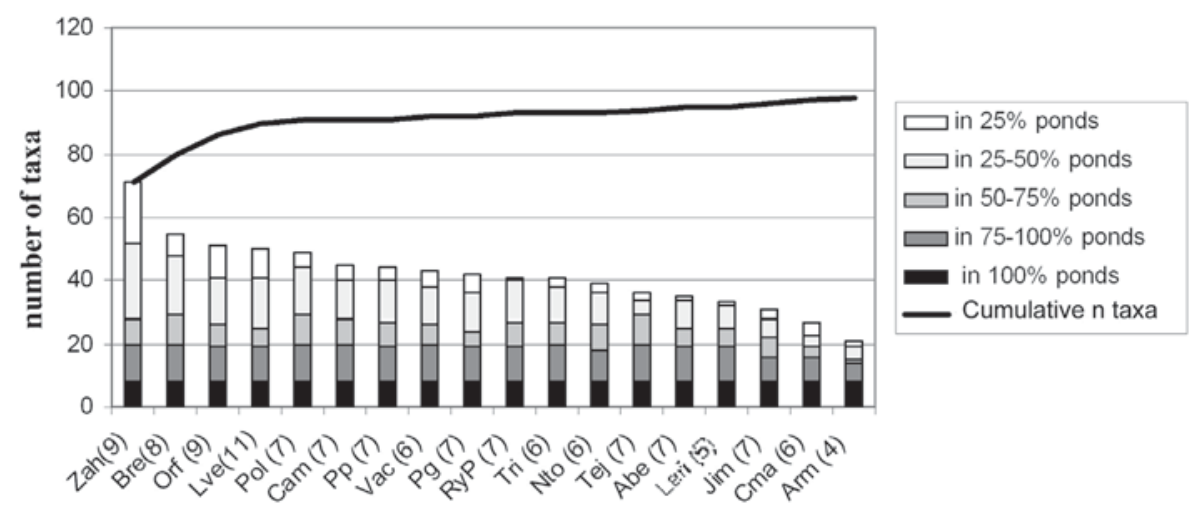

Figure 4. Cumulative number of macroinvertebrate taxa recorded in 18 temporary ponds monthly sampled during their flooding period in 2006-07. Bars indicate the number of taxa detected in different percentages of the sampled ponds. The number of months that ponds were flooded is indicated in brackets after each pond name. Ponds have been ordered after decreasing richness. Número acumulado de taxones de macroinvertebrados registrados en 18 lagunas temporales, muestreadas mensualmente durante el periodo de inundación de 2006-07. Las barras indican el número de taxones detectados en cada laguna, clasificados según su aparición en el porcentaje indicado de lagunas muestreadas. El número de meses que cada laguna estuvo inundada se indica entre paréntesis tras su nombre. Las lagunas se han ordenado en orden decreciente de riqueza específica. 
Table 3. Number of taxa of the different families and orders of macroinvertebrates recorded in the Doñana ponds. The number of different genera and species recorded are also indicated, while - means that only the family or order could be identified. Número de taxones de macroinvertebrados registrados en las lagunas temporales de Doñana. Se indica también el número de especies y géneros diferentes registrados. Se indica - cuando sólo se pudo identificar hasta familia u orden.

\begin{tabular}{|c|c|c|c|c|}
\hline Order & Family & $N$ genera & $N$ species & $N$ taxa \\
\hline Coleoptera & $\begin{array}{l}\text { Chrysomelidae } \\
\text { Curculionidae } \\
\text { Dryopidae } \\
\text { Dytiscidae } \\
\text { Gyrinidae } \\
\text { Haliplidae } \\
\text { Helophoridae } \\
\text { Hydraenidae } \\
\text { Hydrochidae } \\
\text { Hydrophilidae } \\
\text { Paelobiidae } \\
\text { Noteridae } \\
\text { Scirtidae }\end{array}$ & $\begin{array}{c}1 \\
2 \\
1 \\
15 \\
1 \\
1 \\
1 \\
3 \\
1 \\
10 \\
1 \\
1 \\
1\end{array}$ & $\begin{array}{c}- \\
4 \\
1 \\
21 \\
1 \\
3 \\
2 \\
5 \\
1 \\
14 \\
1 \\
1 \\
-\end{array}$ & 56 \\
\hline Heteroptera & $\begin{array}{l}\text { Corixidae } \\
\text { Notonectidae } \\
\text { Nepidae } \\
\text { Pleidae } \\
\text { Naucoridae } \\
\text { Microveliidae } \\
\text { Gerridae } \\
\text { Saldidae }\end{array}$ & $\begin{array}{l}5 \\
2 \\
1 \\
1 \\
1 \\
1 \\
1 \\
-\end{array}$ & $\begin{array}{l}8 \\
4 \\
1 \\
1 \\
1 \\
1 \\
2 \\
-\end{array}$ & 19 \\
\hline Odonata & $\begin{array}{l}\text { Libellulidae } \\
\text { Lestidae } \\
\text { Coenagrionidae } \\
\text { Aeshnidae }\end{array}$ & $\begin{array}{l}2 \\
1 \\
2 \\
3\end{array}$ & $\begin{array}{l}5 \\
4 \\
3 \\
4\end{array}$ & 16 \\
\hline Acari & & - & - & 1 \\
\hline Bassomatophora & $\begin{array}{l}\text { Physidae } \\
\text { Planorbidae }\end{array}$ & $\begin{array}{l}1 \\
-\end{array}$ & $\begin{array}{l}- \\
- \\
-\end{array}$ & 2 \\
\hline Decapoda & Cambaridae & 1 & 1 & 1 \\
\hline Diptera & $\begin{array}{l}\text { Ceratopogonidae } \\
\text { Chaoboridae } \\
\text { Culicidae } \\
\text { Dixidae } \\
\text { Chironomidae } \\
\text { Dolichopodidae } \\
\text { Ephydridae } \\
\text { Rhagionidae } \\
\text { Scatophagidae } \\
\text { Sciomyzidae } \\
\text { Syrphidae }\end{array}$ & $\begin{array}{l}- \\
- \\
- \\
- \\
3 \\
- \\
- \\
- \\
- \\
- \\
-\end{array}$ & $\begin{array}{l}- \\
- \\
- \\
- \\
1 \\
- \\
- \\
- \\
- \\
- \\
-\end{array}$ & 16 \\
\hline
\end{tabular}


Table 3. (cont.)

\begin{tabular}{|c|c|c|c|c|}
\hline Order & Family & $N$ genera & $N$ species & $N$ taxa \\
\hline & $\begin{array}{l}\text { Tabanidae } \\
\text { Thaumelidae } \\
\text { Tipulidae }\end{array}$ & $\begin{array}{l}- \\
- \\
-\end{array}$ & $\begin{array}{l}- \\
- \\
-\end{array}$ & \\
\hline Ephemeroptera & Baetidae & 1 & - & 1 \\
\hline Haplotaxida & $\begin{array}{l}\text { Lumbricidae \& Sparganophilidae } \\
\text { Tubificidae }\end{array}$ & $\begin{array}{l}- \\
-\end{array}$ & - & 2 \\
\hline Lumbriculida & Lumbriculidae & - & - & 1 \\
\hline Isopoda & Asellidae & 1 & 1 & 1 \\
\hline Notostraca & Triopsidae & 1 & 1 & 1 \\
\hline Anostraca & $\begin{array}{l}\text { Branchipodidae } \\
\text { Chirocephalidae } \\
\text { Streptocephalidae } \\
\text { Tanymastigiidae }\end{array}$ & $\begin{array}{l}1 \\
1 \\
1 \\
1\end{array}$ & $\begin{array}{l}2 \\
1 \\
1 \\
1\end{array}$ & 5 \\
\hline Conchostraca & $\begin{array}{l}\text { Cyzicidae } \\
\text { Leptestheriidae }\end{array}$ & $\begin{array}{l}1 \\
1\end{array}$ & $\begin{array}{l}1 \\
1\end{array}$ & 2 \\
\hline
\end{tabular}

Pelophylax perezi mainly breeds in permanent waters and in Doñana is common only in those ponds that have been artificially deepened to persist during the summer, therefore being extended through different zones across the Park. The other two species are scarce or rare in the area: Bufo bufo is restricted to the scarce permanent ponds, and Alytes cisternasii is restricted to a small area with streams to the North of the Park (Díaz-Paniagua et al., 2006).

As a consequence of the wide differences in rainfall, and in pond hydroperiod observed among years (Fig. 2), temporary ponds also differed in the number of breeding species. To illustrate this variation, we show the abundance of the amphibian larvae in three ponds with different hydroperiod in subsequent years of different rainfall, including a dry year in which ponds were not filled (2004-05) and amphibians did not breed. In the pond with shortest hydroperiod, Bufo calamita was the predominant species in a dry year (2005-06), while in years of higher rainfall Triturus pygmaeus was predominant. In the intermediate pond, Hyla meridionalis and T. pygmaeus were predominant in most of the years, but in the very rainy year (2003-04) Lissotriton boscai reached the highest abundances. In the pond of long hydroperiod we also detected differences in species abundance, mainly in the two last years with predominance of Hyla meridionalis in 200506 and of Pelobates cultripes in 2006-07 (Fig. 5).

\section{DISCUSSION}

Doñana National Park includes a high number of ponds which widely differ in their extent and hydroperiod, configuring a network of aquatic habitats. The characteristics of these ponds coincide with the main description of Mediterranean temporary ponds (see Zacharias et al., 2007), as they are formed on shallow depressions on sandy sub- 


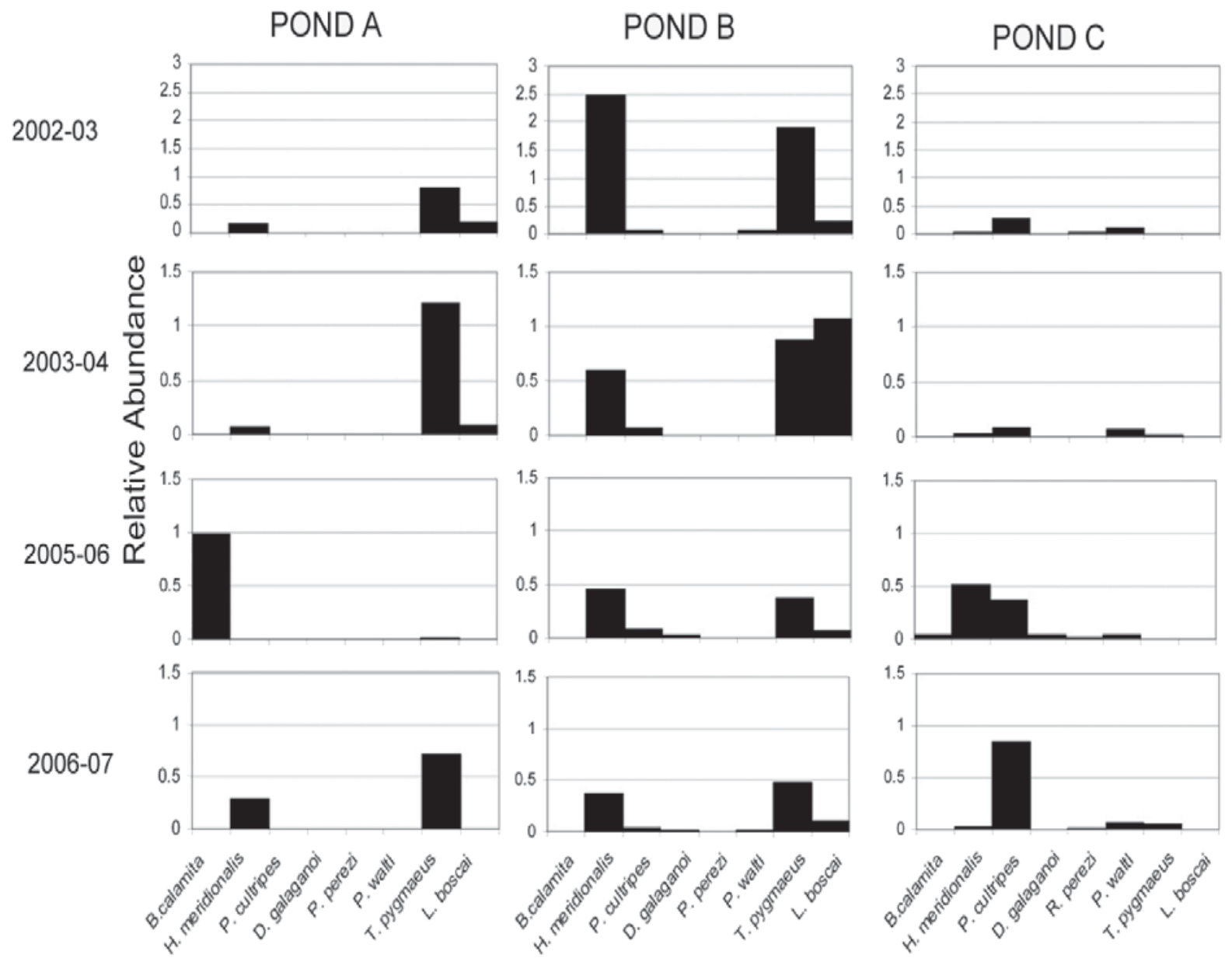

Figure 5. Relative abundance (number of larvae/total number of sampling units) of the amphibian larvae recorded in three ponds of different hydroperiod, sampled from 2002 to 2007 (In the dry year 2004-05 ponds were not filled). A: pond of usually short hydroperiod; B: pond of usually intermediate hydroperiod; C: extensive pond of usually long hydroperiod. Abundancia relativa (número de larvas/número total de unidades de muestreo de larvas de anfibios registrada en tres lagunas de diferente hidroperiodo, muestreadas entre 2002 y 2007 (no se inundaron en el año de sequía 2004-05). A: lagunas que tienen normalmente un hidroperiodo corto; B: lagunas que presentan normalmente un hidroperiodo intermedio; C: lagunas de amplia extensión que habitualmente presentan un largo hidroperiodo.

strate and show a wide variability in hydroperiod, and in the seasonal initiation of inundation. Some ponds are mainly filled by runoff water, while others, mainly those of longer water persistence are also fed by groundwater (García Novo et al., 1991; Serrano et al., 2006; Gómez-Rodriguez et al., 2009). A comparison of their water chemistry with other temporary ponds in Mediterranean Region was made in Gómez-Rodriguez et al. (2009), being within the range of conductivity reported for Mediterranean temporary ponds in
Zacharias et al. (2007), similar to the ponds in southern Portugal (Beja \& Alcazar, 2003) and with lower $\mathrm{pH}$ and conductivity than ponds in southern France (Waterkeyn et al., 2008). Compared with other aquatic media of the same area, temporary ponds did not widely differ (Serrano \& Toja, 1995; Serrano et al., 2006; Espinar \& Serrano, 2009).

While temporary ponds are generally threatened aquatic habitats, which have been largely unfavoured and often destroyed by human actions to favour agriculture or urban development 
(Williams et al. 2001; Grillas et al., 2004), the system of temporary ponds in Doñana has been preserved under the integral protection of a National Park. The particular hydrology of this area and the low human activities have favoured the persistence of the smooth depressions on which water may temporally persist due to the presence of high organic matter content and of semipermeable horizons in their soils. These characteristics were related to the presence of a granulometrical discontinuity in depth, a Mio-Pliocene relic horizon of semi permeable sediments with high iron content (Clemente et al., 1993) which favours the presence of a hanging water-table and contributes through a feedback process to elongate the flooding period, improves the clay-silty deposit and increase the thickness of the organic horizon. In fact, the high number of ponds of natural origin that we describe for Doñana has not been reported in other European areas, although many ponds of small size may have frequently been overlooked in ponds inventories, as also were most temporary ponds in Doñana in previous studies (e.g. Bravo \& Montes (1990) made an inventory of 308 ponds).

In Doñana ponds, hydroperiod is conditioned by the timing and amount of rainfall within a particular year, and even the year before during dry periods (Serrano \& Zunzunegui, 2008). Our data illustrate the wide variation that ponds may experience among years as the same pond may be extensive and with a long hydroperiod during wet years whereas it may become a short-duration pond in drier years. Moreover, locations shallowly flooded in wet years may be completely dry in others, and therefore even the number of temporary aquatic habitats is variable among years. This variation confers a temporal heterogeneity to the area in which some years the same habitat may be favourable for some species and other years may be unsuitable for these but adequate for others (Gómez-Rodríguez et al., 2009). In view of such wide variations in pond water permanence, it is not possible to make a static classification of the ponds regarding their duration or hydroperiod, though classifications can be assessed within the same year or making reference to particular types of years.
Temporary ponds are important because they are specific habitats for many organisms which do not survive in permanent ponds, including endemic, rare or endangered species (Collinson et al., 1995; Grillas et al., 2004; Nicolet et al., 2004; Della Bella et al., 2008; Bilton et al., 2008). They are the main breeding habitats of most amphibian species in temperate areas (see e.g. Semlitsch, 2003; Wells, 2007). While species richness may be low in small ponds, the number of species associated to these habitats increases with the number of ponds included in an area (Collinson et al., 1995; Grillas et al., 2004). In this sense, the high number of ponds in Doñana favours the conservation of a high number of species of different aquatic taxonomical groups. Regarding plant species, out of the 83 aquatic plant species recorded in the area of Doñana (García-Murillo et al., 2006; Fernández-Zamudio et al., unpublished data), 68 were found in temporary ponds. About $25 \%$ of the species recorded are presently included in national or regional lists of threatened flora with different IUCN categories (Cirujano et al., 1992; Sergio et al., 1994; Bañares et al., 2003; Cabezudo et al., 2005). Some examples are Thorella verticillato-inundata, Lemna trisulca, Wolfia arrhiza, Zannichellia obtusifolia or Hydrocharis morsus-ranae. The latter is the most threatened species of our list and Doñana maintains one of the only two Spanish populations (Cirujano \& Medina, 2002). The presence of these species and habitats in European and National lists enhances the value of the Doñana temporary ponds for the conservation of aquatic vegetation.

Regarding faunistic biodiversity, a high richness of microcrustaceans, and rotifers has been reported for Doñana Ponds (Fahd et al., 2009). Most of these species were derived from several sources, including tropical, Ethiopic, and NorthAfrican origins (Miracle, 1982), but also endemic species of special interest are included, being in this area common or even abundant species. Also a high richness is found in macroinvertebrate fauna. In the aquatic media of Doñana, including the temporary ponds system, two permanent large ponds and the nearby marsh, 110 species of aquatic coleoptera have been reported (Millán et al., 2005), a richness similar or even higher 
comparing with other temporary (Bazzanti et al., 1996; Schneider \& Frost, 1996; Brooks, 2000; Boix et al., 2001) and permanent ponds (Heino, 2000; Della Bella, 2005). Collinson et al. (1995) found that although a small number of species were characteristics of many temporary ponds, an ensemble of temporary ponds did not differ in species richness from large permanent ponds. In our study area, also a similar increase in total richness of macroinvertebrates and amphibians is observed when data from different temporary ponds are accumulated, in spite of the low richness of some small ponds.

Thus, some studies have claimed that for the conservation of biodiversity of temporary pond species, it is more important to preserve an area with a system of temporary ponds, configuring a network of ponds of different characteristics and water regime that the preservation of isolated large ponds (Oertli et al., 2002; Beja \& Alcazar, 2003; Cheylan, 2004; Angelibert et al., 2004; Zacharias et al., 2007; Bilton et al., 2008). In this sense, the temporary ponds system in Doñana National Park may represent a good example of a network of aquatic habitats. The high number of ponds of different size experienced wide differences in hydroperiod, within and among years, and the whole system has been proven to be a robust network of breeding sites for amphibians in rainy years, and even in years of low annual rainfall (Fortuna et al., 2006).

In this study we show the wide differences that may be observed among ponds in the number and identity of amphibian species, which are even increased in different annual periods. The annual period of inundation or hydroperiod of temporary ponds constrains the number of species that a pond may include (Pechmann et al., 1989; Díaz-Paniagua, 1992; Snodgrass et al., 2000), especially for those species with reproductive aquatic phases requiring a minimum period to be completed (as in this area the larvae of some amphibian species, see Díaz-Paniagua, 1988). In general, amphibian fauna is well preserved in the Doñana National Park, and 11 of the 13 species of SW Spain are found in this area (Díaz-Paniagua et al., 2006). This is mainly due to the fact that most of the species are pond breeders (Díaz-Paniagua, 1990), and this area provides a wide availability of optimal breeding habitats. The system of temporary ponds of Doñana provides a wide heterogeneity of ponds, with different extent and duration, which is even larger at a longer temporal scale due to interannual differences in rainfall. For a same pond, hydroperiod will change in time, and consequently their dominant species, thus ponds may be optimal habitats for different species in different years (Semlisch, 2003), and these changes favour the whole community in the long-term (see Gómez-Rodríguez, 2009 for a detailed analysis in this pond system). Similar arguments may be extended to other faunistic species, such as macroinvertebrates and zooplankton.

The Doñana ponds represent an example of conservation of temporary aquatic habitats because no single or isolated ponds are preserved, but a whole area with a high density and heterogeneity of temporary ponds. This system provides habitats for a wide number of plant and animal aquatic or semi-aquatic species, most of them unable to survive in permanent waters and many of them under threat. This system has been indirectly preserved due to the integral protection of a National Park, but as other temporary ponds system is also presently threatened by several factors, as the invasion of exotic species, and mainly by the risk of desiccation or hydroperiod shortening due to overexploitation of ground water (Manzano \& Custodio, 2006; Serrano \& Zunzunegui, 2008; Serrano et al., 2008; Gómez-Rodríguez, 2009). A specific management of the temporary pond system should be required to adopt particular measurements to prevent the present threats and to preserve such valuable habitats.

\section{ACKNOWLEDGEMENTS}

This study was funded by the Spanish Ministry of Science and Education and EU FEDER funds (CGL2006-04458/BOS) and Junta de Andalucía (Excellence Research Project RNM 932) and Fellowship grants CSIC-I3P (European Union Social Funds) to M.F. and AP-2001-3475 to C.G.-R. and JA-2003 to R.F.-Z., and JA-2005 to A.P. 


\section{REFERENCES}

ALONSO, M. 1996. Crustacea, Branchiopoda. In: Fauna Ibérica. M. A. Ramos (ed.): vol 7: 1-486. Museo Nacional de Ciencias Naturales, CSIC, Madrid.

ANGELIBERT, S., P. MARTY, R. CÉRÉGHINO \& N. GIANI. 2004. Seasonal variations in the physical and chemical characteristics of ponds: implications for biodiversity conservation. Aquatic Conservation: Marine and Freshwater Ecosystems, 14: 439-456.

BAÑARES, Á., G. BLANCA, J. GÜEMES, J. C. MORENO \& S. ORTIZ. 2003. Atlas y libro rojo de la flora vascular amenazada de España. Madrid: Dirección General de Conservación de la Naturaleza. $1069 \mathrm{pp}$.

BAZZANTI, M., S. BALDONI \& M. SEMINARA. 1996. Invertebrate macrofauna of a temporary pond in Central Italy: composition, community parameters and temporal succession. Archiv für $\mathrm{Hy}$ drobiologie, 137: 77-94.

BEJA, P. \& R. ALCAZAR. 2003. Conservation of Mediterranean temporary ponds under agricultural intensification: an evaluation using amphibians. Biological Conservation, 114: 317-326.

BILTON, D. T., L. C. MCABENDROTH, P. NICOLET, A. BEDFORD, S. D. RUNDLE, A., FOGGO \& P.M. RAMSAY. 2008. Ecology and conservation status of temporary and fluctuating ponds in two areas of Southern England. Aquatic Conservation: Marine and Freshwater Ecosystems, 19: 134146.

BOIX, D., J. SALA, \& R. MORENO-AMICH. 2001. The faunal composition of Espolla pond (NE Iberian Peninsula): the neglected biodiversity of temporary waters. Wetlands, 21: 577-592.

BRAVO, M. A. \& C. MONTES. 1993. Inventario de las formaciones palustres del Manto Eólico del Parque Nacional de Doñana (SW España). Actas VI Congreso Español de Limnología: 31-43.

BRÖNMARK, C. \& L.-A. HANSSON. 2005. The Biology of Lakes and Ponds. Oxford: Oxford University Press. 285 pp.

BROOKS, R. T. 2000. Annual and seasonal variation and the effects of hydroperiod on benthic macroinvertebrates of seasonal forest ("vernal") ponds in Central Massachusetts, USA. Wetlands, 20: 707715.

CABEZUDO, B., S. TALAVERA, G. BLANCA, C. SALAZAR, M. CUETO, B. VALDÉS, J. E.
HERNÁNDEZ BERMEJO, C. M. HERRERA, C. RODRÍGUEZ HIRALDO \& D. NAVAS. 2005. Lista roja de la flora vascular de Andalucía. Sevilla: Consejería de Medio Ambiente (Junta de Andalucía). 126 pp.

CAYROU, J. \& R. CÉRÉGHINO. 2005. Life-cycle phenology of some aquatic insects: implication for pond conservation. Aquatic Conservation: Marine and Freshwater Ecosystems, 15: 559-571.

CÉRÉGHINO, R., J. BIGGS, B. OERTLI \& S. DECLERCK. 2008. The ecology of European ponds: defining the characteristics of a neglected freshwater habitat. Hydrobiologia, 597: 1-6.

CHEYLAN, M. 2004. Amphibians. In: Mediterranean Temporary Pools; volume 1- Issues relating to conservation, functioning and management. P. Grillas, P. Gauthier, N. Yavercovski \& C. Perennou (eds.): 26-32. Arles: Station Biologique de la Tour du Valat.

CIRUJANO, S. \& L. MEDINA. 2002. Plantas acuáticas de las lagunas y humedales de Castilla-La Mancha. Madrid: Real Jardín Botánico, CSICJunta de Comunidades de Castilla-La Mancha. 340 pp.

CIRUJANO, S., M. VELAYOS, F. CASTILLA \& M. GIL. 1992. Criterios botánicos para la valoración de las lagunas y humedales españoles (Península Ibérica y las Islas Baleares). Madrid: ICONAC.S.I.C. 456 pp.

CIRUJANO, S., J. CAMBRA, P. M. SÁNCHEZCASTILLO, A. MECO \& N. FLOR ARNAU. 2007. Flora Ibérica. Algas continentales. Carófitos (Characeae). Madrid: Real Jardín BotánicoC.S.I.C. 132 pp.

CLEMENTE, L., P. SILJESTRÖM \& L. V. GARCÍA. 1993. Evolución geo-edáfica del sistema eólico del Parque Nacional de Doñana durante el Holoceno. In: El Cuaternario de España y Portugal: 955-960. Instituto Tecnológico Geominero de España, Madrid.

COLLINSON, N. H., J. BIGGS, A. CORFIELD, M. J. HODSON, D. WALKER, M. WHITFIELD \& P. J. WILLIAMS. 1995. Temporary and permanent ponds: An assessment of the effects of drying out on the conservation value of aquatic macroinvertebrate communities. Biological Conservation, 74: 123-133.

DELLA BELLA, V., M. BAZZANTI \& F. CHIAROTTI. 2005. Macroinvertebrate diversity and conservation status of Mediterranean ponds in 
Italy: water permanence and mesohabitat influence. Aquatic Conservation: Marine and Freshwater Ecosystems, 15: 583-600.

DELLA BELLA, V., M. BAZZANTI, M. G. DOWGIALLO \& M. IBERITE. 2008. Macrophyte diversity and physico-chemical characteristics of Tyrrhenian coast ponds in central Italy: implications for conservation. Hydrobiologia, 597: 85-95.

DENOËL, M. 2004. Répartition, habitat et conservation des amphibiens du Pays de Herve (Belgique). Bulletin Société Herpétologique France, 111-112: 49-77.

DÍAZ-PANIAGUA, C. 1988. Temporal segregation in larval amphibian communities in temporary ponds at a locality in SW Spain. AmphibiaReptilia, 9: 15-26.

DÍAZ-PANIAGUA, C. 1990. Temporary ponds as breeding sites of amphibians at a locality in southwestern Spain. Herpetological Journal, 1: 447453.

DÍAZ-PANIAGUA, C. 1992. Variability in timing of larval season in an amphibian community in SW Spain. Ecography, 15: 267-272.

DÍAZ-PANIAGUA C., C. GÓMEZ-RODRÍGUEZ, A. PORTHEAULT \& W. DE VRIES. 2005. Los Anfibios de Doñana. Madrid:Organismo Autónomo de Parques Nacionales. Ministerio de Medio Ambiente. 181 pp.

DÍAZ-PANIAGUA C., C. GÓMEZ-RODRÍGUEZ, A. PORTHEAULT \& W. DE VRIES. 2006. Distribución de los anfibios del Parque Nacional de Doñana en función de la densidad y abundancia de los hábitats de reproducción. Revista Española de Herpetología, 20: 17-30.

EUROPEAN COMMISSION DG ENVIRONMENT. 2007. Interpretation Manual of European Union Habitats. EUR, 27: 1-142.

ESPINAR, J. L. \& L. SERRANO. 2009. A quantitative hydrogeomorphic approach to the classification of temporary wetlands in the Doñana National Park (SW Spain). Aquatic Ecology, 43: 323-324.

FAHD, K., L. SERRANO \& J. TOJA. 2000. Crustacean and rotifer composition of temporary ponds in the Doñana National Park (SW Spain). Hydrobiologia, 436: 41-49.

FAHD, K., A. ARECHEDERRA, M. FLORENCIO, D. LEÓN \& L. SERRANO. (2009). Copepods and Branchiopods of temporary ponds in the Doñana Natural Area (SW Spain): a four-decade record (1964-2007). Hydrobiologia, 634: 219-230.
FAO 1977. Guidelines for Soil Profile Description, $2^{\text {nd }}$ edition. Rome: FAO. $66 \mathrm{pp}$.

FLORENCIO, M., L. SERRANO, C. GÓMEZ-RODRÍGUEZ, A. MILLÁN \& C. DÍAZ-PANIAGUA, 2009. Inter and intra-annual variation of macroinvertebrate assemblages in temporary ponds from the Doñana National Park (SW Spain). Hydrobiologia, 634: 167-183.

FORTUNA, M., C. GÓMEZ-RODRÍGUEZ \& J. BASCOMPTE. 2006. Spatial network structure and amphibian persistence in stochastic environments. Proceedings of the Royal Society B: Biological Sciences, 273: 1429-1434.

GALINDO, M. D., L. SERRANO, H. SEGERS \& N. MAZUELOS. 1994. Lecane donyanaensis $n$. $s p$. (Rotifera: Monogononta, Lecanidae) from the Doñana National Park (Spain). Hydrobiologia, 284: 235-239.

GARCÍA-MURILLO, P. J., R. FERNÁNDEZ-ZAMUDIO, S. CIRUJANO \& A. SOUSA. 2006. Aquatic macrophytes in Doñana protected area (SW Spain): An overview. Limnetica, 5: 71-80.

GARCÍA NOVO, F., D. GALINDO, J. A. G. SÁNCHEZ, C. GUISANDO, J. JAÚREGUI, T. LÓPEZ, N. MAZUELOS, J. C. MUÑOZ, L. SERRANO \& J. TOJA. 1991. Tipificación de los ecosistemas acuáticos sobre sustrato arenoso del Parque Nacional de Doñana. III Simposium de Aguas de Andalucia, Córdoba, España: 165-176.

GARCÍA NOVO, F. \& C. MARÍN. 2006. Doñana Water and Biosphere. Madrid: Doñana 2005, Confederación Hidrográfica del Guadalquivir, Ministerio Medio Ambiente. 365 pp.

GRILLAS, P., P. GAUTHIER, N. YAVERCOVSKI \& C. PERENNOU. 2004. Mediterranean Temporary Pools; volume 1-Issues relating to conservation, functioning and management. Arles: Station Biologique de la Tour du Valat.

GRIFFITHS, R. A. 1997. Temporary ponds as amphibian habitats. Aquatic Conservation: Marine and Freshwater Ecosystems, 7: 119-126.

GÓMEZ-RODRÍGUEZ, C. 2009. Condicionantes ecológicos de la distribución de anfibios en el Parque Nacional de Doñana. Tesis Doctoral. Universidad de Salamanca. 301 pp.

GÓMEZ-RODRÍGUEZ, C., J. BUSTAMANTE \& C. DÍAZ-PANIAGUA. 2008. High-resolution remote-sensing data in amphibian studies: identification of breeding sites and contribution to habitat models. Herpetological Journal, 18: 103-113. 
GÓMEZ-RODRÍGUEZ, C., C. DÍAZ-PANIAGUA, L. SERRANO, M. FLORENCIO \& A. PORTHEAULT, 2009 . Mediterranean temporary ponds as amphibian breeding habitats: The importance of preserving pond networks. Aquatic Ecology, 43: $1179-1191$

HEINO, J. 2000. Lentic macroinvertebrate assemblage structure along gradients in spatial heterogeneity, habitat size and water chemistry. Hydrobiologia, 418: 229-242.

IUSS WORKING GROUP WRB. 2006. World reference base for soil resources 2006. World Soil Resources Reports No. 103. Rome: FAO. 128 pp.

JAKOB, C., G. POIZAT, M. VEITH, A. SEITZ, \& A. J. CRIVELLI. 2003. Breeding phenology and larval distribution of amphibians in a Mediterranean pond network with unpredictable hydrology. $H y$ drobiologia, 499: 51-61.

LÓPEZ, T., J. TOJA \& N. GABELLONE. 1991. Limnological comparison of two peridunar ponds in the Doñana National Park (Spain). Archiv für Hydrobiologie, 120: 357-378.

MANZANO, M. \& E. CUSTODIO. 2006. The Doñana aquifer and its relations with the natural environment. In: Doñana Water and Biosphere. F. García Novo \& C. Marín (eds.): 141150. Doñana 2005, Confederación hidrográfica del Guadalquivir, Ministerio Medio Ambiente. Madrid.

MAZUELOS, N., J. TOJA \& C. GUISANDE. 1993. Rotifers in ephemeral ponds of Doñana National Park. Hydrobiologia, 255/256: 429-243.

MILLÁN, A., C. HERNANDO, P. AGUILERA. 2005. Los coleópteros acuáticos y semiacuáticos de Doñana: reconocimiento de su biodiversidad y prioridades de conservación. Boletín Sociedad Entomológica Aragonesa, 37: 157-164.

MIRACLE, M. R. 1982. Biogeography of the freshwater zooplanktonic communities of Spain. Journal of Biogeography, 9: 455-467.

NICOLET, P., J. BIGGS, G. FOX, M. J. HODSON, C. REYNOLDS, M. WITHFIELD \& P. WILLIAMS. 2004. The wetland plant and macroinvertebrate assemblages of temporary ponds in England and Wales. Biological Conservation, 120: 265-282.

OERTLI, B., D. A. JOYE, E. CASTELLA, R. JUGE, D. CAMBIN \& J. B. LACHAVANNE. 2002. Does size matter? The relationship between pond area and biodiversity. Biological Conservation, 104: 59-70.
PECHMANN, J. H. K., D. E. SCOTT, J. W. GIBBONS \& R. D. SEMLITSCH. 1989. Influence of wetland hydroperiod on diversity and abundance of metamorphosing juvenile amphibians. Wetlands Ecology and Managements, 16: 564-576.

SCHNEIDER, D. W. \& T. M. FROST. 1996. Habitat duration and community structure in temporary ponds. Journal of the North American Benthological Society, 15: 64-86.

SEMLITSCH, R. D. 2003. Amphibian Conservation. Washington and London: Smithsonian Books. 336 pp.

SERGIO, C., C. CASAS, M. BRUGUÉS \& R. M. CROS. 1994. Lista Vermelha dos Briófitos da Península Ibérica. Lisboa: Instituto da Conservaçao da Natureza; Museu, Laboratório e Jardim Botânico \& Universidade de Lisboa. 45 pp.

SERRANO, L. \& K. FAHD. 2005. Zooplankton communities across a hydroperiod gradient of temporary ponds in the Doñana National Park (SW Spain). Wetlands, 25: 101-111.

SERRANO, L. \& J. TOJA. 1995. Limnological description of four temporary ponds in the Doñana National Park (SW, Spain). Archiv für Hydrobiologie, 133: 497-516.

SERRANO, L. \& M. ZUNZUNEGUI. 2008. The relevance of preserving temporary ponds during drought: hydrological and vegetation changes over a 16-year period in the Doñana National Park (south-west Spain). Aquatic Conservation: Marine and Freshwater Ecosystems, 18: 261-279.

SERRANO, L., M. P. ESQUIVIAS-SEGURA \& M. ZUNZUNEGUI. 2008. Hydrologic and vegetation changes over a 16-year period in the Doñana N. P. (SW Spain). Limnetica, 27: 65-78.

SERRANO, L., M. REINA, G. MARTÍN, I. REYES, A. ARECHEDERRA, D. LEÓN \& J. TOJA. 2006. The aquatic systems of Doñana (SW Spain): watersheds and frontiers. Limnetica, 25: 11-32.

SILJESTRÖM, P. 1985. Geomorfología y Edafogénesis de las Arenas del Parque Nacional de Doñana. Tesis Doctoral. Univ. Sevilla. 515 pp.

SILJESTRÖM, P. \& L. CLEMENTE.1990. Geomorphology and Soil Evolution of a Moving Dune System in SW Spain (Doñana National Park). Journal of Arid Environments, 18: 139-150.

SILJESTRÖM, P., A. MORENO, L. V. GARCÍA, \& L. E. CLEMENTE. 1994. Doñana National Park (south-west Spain): geomorphological characterization through a soil-vegetation study. Journal of Arid Environments, 26: 315-323. 
SNODGRASS, J. W., M. J. KOMOROSKI, A. L. BRIAN, JR., \& J. BURGER. 2000. Relationships among isolated wetland size, hydroperiod, and amphibian species richness: implications for wetlands regulations. Conservation Biology, 14: 414-419.

SOIL SURVEY STAFF. 1993. Soil Survey Manual. Washington DC: US Department of Agriculture. 437 pp.

SOIL SURVEY STAFF. 2006. Keys to Soil Taxonomy, $10^{\text {th }}$ ed. Washington DC: .Natural Resources Conservation Service, United States Department of Agriculture. 200 pp.

STAMATI, F., N. NIKOLAIDIS, E. DIMITRIOU \& T. KOUSSOURIS. 2008. Hydro-geochemical Aspects of Mediterranean Temporary Ponds in Western Crete. Journal of Environmental Quality, 37: 164-173.

VALDÉS, B., S. TALAVERA \& E. F. GALIANO. 1987. Flora Vascular de Andalucía Occidental. Barcelona: Ketres Editores. 485 pp.

VERDÚ, J. R. \& E. GALANTE (eds.) 2005. Libro Rojo de los Invertebrados de España. Madrid: Dirección General de Conservación de la Naturaleza. 411 pp.

WATERKEYN, A., P. GRILLAS, B. VANSCHOEN-
WINKEL \& L-BRENDONCK. 2008. Invertebrate community patterns in Mediterranean temporary wetlands along hydroperiod and salinity gradients. Freshwater Biology, 53: 1808-1822.

WELLBORN, G. A., D. K. SKELLY \& E. E. WERNER. 1996. Mechanisms creating community structure across a freshwater habitat gradient. Annual Review of Ecology and Systematic, 27: 337363.

WELLS, K. D. 2007. The ecology and behavior of amphibians. Chicago: University of Chicago Press. 1148 pp.

WILLIAMS, D. D. 2006. The Biology of Temporary Waters. Oxford: Oxford University Press. 337 pp.

WILLIAMS, P., J. BIGGS, G. FOX, P. NICOLET \& M. WHITFIELD. 2001. History, origins and importance of temporary ponds. In: European Temporary Ponds: A Threatened Habitat.: 7-15. Freshwater Biological Association (ed.) Birmingham: Freshwater Biological Association.

ZACHARIAS, I., E. DIMITROU, A. DEKKER \& E. DORSMAN. 2007. Overview of temporary ponds in the Mediterranean region: Threats, management and conservation issues. Journal of Environmental Biology, 28: 1-9. 